\title{
Fellowship and Food in the Kingdom
}

\section{Eschatological Meals and Scenes of Utopian Abundance in the New Testament}

[Mahl und Nachfolge im Königreich. Untersuchungen zum eschatologischen Mahl und zu neutestamentlichen Utopien von Nahrung im Überfluß.]

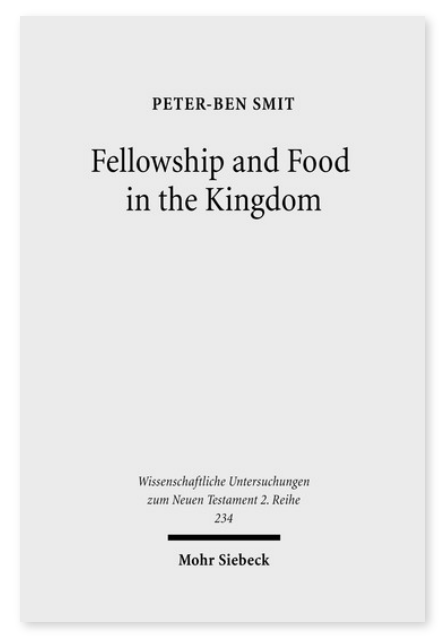

2008. XV, 496 Seiten. WUNT II 234

ISBN 978-3-16-151577-4

DOI 10.1628/978-3-16-151577-4

eBook PDF 109,00€

ISBN 978-3-16-149271-6

fadengeheftete Broschur 109,00€
Veröffentlicht auf Englisch.

Peter-Ben Smit unternimmt die erste umfassende Untersuchung der eschatologischen Mahlzeiten im Neuen Testament sowie der Szenen, in denen von Nahrung im Überfluß gesprochen wird. Er stellt die entsprechenden Textstellen in ihren soziohistorischen Kontext und zeigt ihren Zusammenhang mit zeitgenössischen Vorstellungen von Symposien auf. Der synchrone Aufbau des Buches verdeutlicht, wie die untersuchten Textstellen mit den vier Evangelien und der Johannesoffenbarung interagieren.

Peter-Ben Smit Born 1979; MA in Theology at University of Amsterdam; MA in Biblical Studies at the Departement of Biblical Studies, University of Sheffield; 2005 Ordination; 2005 Promotion to Dr. Theol.; Doctoral student at the General Theological Seminary, New York City; Assisting priest in the parish of St. Ann, Sayville, Long Island.

Jetzt bestellen:

https://mohrsiebeck.com/buch/fellowship-and-food-in-the-kingdom-9783161515774?no_cache=1

order@mohrsiebeck.com

Telefon: +49 (0)7071-923-17

Telefax: $+49(0) 7071-51104$ 